\title{
MEMBANGUN KOMUNIKASI PARTISIPATIF MASYARAKAT UPAYA MELESTARIKAN TANAMAN SALAK LOKAL DI MANONJAYA TASIKMALAYA
}

\author{
Dian Sinaga $^{1}$, Yunus Winoto ${ }^{2}$, Fitri Perdana ${ }^{3}$ \\ 1,2,3 Program Studi Ilmu Perpustakaan Fikom Unpad \\ 1diansinaga21@gmail.com, 2yunuswinoto@gmail.com, fitriperdana79@gmail.com
}

ABSTRACT - The purpose of this study was to determine the communications com- munity participation in the preservation of local barking plant in the district of Tasikmalaya regency Manonjaya. The focus of the study include mental engagement and sense of community in an effort to preserve local plant Manonjaya bark; people's willingness to make a move replanting barking in their respective communities; responsibilities of members of the public in maintaining and sustaining the plant bark and participatory communication activities were made public in building awareness of the importance of conserving plant bark. The method used in this research using mixed methods (mixed method). The combined method is essentially a strategy that uses quantitative and qualitative research in a single study. The results of this research note that 1). Mental and feeling of community involvement Salak farmers in the district and subdistrict Manonjaya Cineam seen from the fear of loss of crops barking in the area that has become the hallmark of their area. 2). Regarding the willingness of society, especially farmers replant barking to start barking. 3). As a form of community responsibility in maintaining the plant bark is to keep and maintain their plants. As for other measures that do well is to find the seeds of the plant bark with trying to combine local salak with pondoh. 4). Then the communication process of public participation in the preservation of local bark visible with the more active farmers in the bark and community leaders to discuss and determine the ideas for solving the problem of the scarcity of plants barking in the District and Sub-district Manonjaya Cineam.

Keywords: Communication participation, preserve local plant, salakfarmers

ABSTRAK - Tujuan penelitian ini adalah untuk mengetahui komunikasi partisipasi ma- syarakat dalam upaya pelestarian tanaman salak lokal di Kecamatan Manonjaya Kabupaten Tasikmalaya. Fokus penelitian ini meliputi keterlibatan mental dan perasaan masyarakat dalam upaya melestarikan tanaman salak lokal Manonjaya; kesediaan masyarakat untuk melakukan gerakan penanaman kembali salak di lingkungannya masing-masing; tanggungjawab anggota masyarakat dalam memelihara dan mempertahankan tanaman salak serta kegiatan komunikasi partisipatif yang dilakukan masyarakat dalam membangun kesadaran akan pentingnya melestarikan tanaman salak. Metode yang digunakan dalam penelitian ini mengunakan metode campuran (mixed method). Hakekatnya metode gabungan adalah merupakan strategi yang mengunakan penelitian kuantitatif dan kualitatif dalam satu penelitian. Hasil dari penelitian ini diketahui bahwa 1). Keterlibatan mental dan perasaan masyarakat petani Salak di Kecamatan Manonjaya dan kecamatan Cineam terlihat dari adanya rasa kekhawatiran akan hilangnya tanaman salak di daerahnya yang telah menjadi ciri khas daerah mereka. 2). Mengenai kesediaan masyarakat khususnya para petani salak untuk mulai menanam kembali salak. 3). Sebagai wujud tanggungjawab masyarakat dalam mempertahankan tanaman salak yaitu dengan tetap menjaga dan memelihara tanaman mereka. Adapun upaya lain yang dilakukan juga adalah dengan mencari bibit tanaman salak dengan mencoba memadukan antara tanaman salak lokal dengan salak pondoh. 4). mengenai proses komunikasi partisipasi masyarakat dalam pelestarian salak lokal terlihat dengan semakin aktifnya para petani salak dan tokoh masyarakat dalam membicarakan dan menentukan ide untuk pemecahan masalah mengenai kelangkaan tanaman salak di wilayah Kecamatan Manonjaya dan Kecamatan Cineam.

Kata Kunci: Komunikasi partisipasi, pelestarian tanaman lokal, petani salak

\section{PENDAHULUAN}

Nama tanaman salak atau dalam bahasa latinnya salacca edulis adalah merupakan tanaman holtikultura yang mulai banyak digemari 
masyarakat. Selain itu juga tanaman salak ini merupakan salah satu tanaman yang cocok untuk dikembangkan di Indonesia. Berkaitan dengan hal ini, ada beberapa kelebihan dari tanaman salak yakni: (1) bertani salak sangat mudah dan tidak perlu perawatan khusus yang rumit, (2) Hama atau penyakit pada tanaman salak relatif tidak ada serta (3) tanaman salak mempunyai umur yang relatif panjang sehingga dapat memberikan hasil dalamjangka waktu yang lama.

Berbicara tentang tanaman salak, di wilayah Kabupaten Tasikmalaya sudah sejak lama terkenal ada suatu daerah menjadi sentra salak lokal yakni Kecamatan Manonjaya dan Kecamatan Cineam. Kedua kecamatan ini terkenal sebagai penghasil salak potensial di wilayah Kabupaten Tasikmalaya. Pada masa kejayaannya, salak di wilayah ini yakni sekitar tahun 1970 sampai tahun 1980an, salak menjadi komoditi unggulan, dan menjadi mata pencaharian masyarakat di wilayah Kecamatan Manonjaya dan Kecamatan Cineam, bahkan sampai ke perbatasan Kabupaten Ciamis yakni Kecamatan Cimaragas. Hampir disepanjang jalan raya antara Kecamatan Manonjaya dan Kabupaten Ciamis melalui daerah Kec. Cimaragas dipenuhi dengan rimbunnya pepohonan salak. Selain itu juga disetiap 100 meter dari jalan tersebut berdiri warungwarung yang menjual buah salak dan hasil bumi lainnya. Salak yang dikenal dengan nama salak Manonjaya dengan rasanya manis dan sedikit sepet (keset), dengan memilik daging buah yang tebal serta memiliki aroma harum. Selain itu juga pada masa kejayaan salak Manonjaya ini, produksinya bisa menembus beberapa daerah di Jawa Barat dan Provinsi lain bahkan waktu itu sempat menjadi komoditas ekspor untuk beberapa negara seperti Belanda, Amerika dan negara Eropa lainnya.

Namun demikian nampaknya masa kejayaan salak di wilayah Kecamatan Manonjaya dan sekitarnya makin hari semakin memudar. Deretan pepohonan salak di pinggir jalan antara Kecamatan Manonjaya dengan Kecamatan Cimaragas Kabupaten Ciamis sudah jarang dijumpai, pengepul dan bandar-bandar salak sudak mulai banyak yang beralih menjadi profesi lain. Selain itu juga beberapa petani salak sedikit demi sedikit mulai mengganti tanamannya dengan tanaman lain seperti tanaman keras dari mulai tanaman albasia, jabon, jati putih, dan lain-lain. Dengan mengganti tanaman salak dengan jenis tanaman keras ini dianggap akan memberikan harapan lebih baik ketimbang harus menanam pohon salak meskipun untuk bisa menikmati hasilnya paling cepat 3-5 tahun, namun harga dari jenis tanaman keras ini sangat menggiurkan para pemilik lahan di wilayah Kecamatan Manonjaya dan Kecamatan Cineam. Selain mengganti dengan tanaman keras ada juga beberapa petani salak yang mengganti tanaman salaknya dengan tanaman pepaya california dan tanaman pisang. Apabila dibandingkan dengan tanaman keras, tanaman ini (pepaya dan pohon pisang) bisa dengan cepat dalam memperoleh hasilnya. Adanya fenomena ini juga dipertegas dengan produksi salak Manonjaya semakin menurun dari tahun ke tahun. 
Adanya penurunan produksi salak lokal Manonjaya serta keengganan para petani salak untuk mempertahankan tanaman salaknya, mengundang keprihatinan dari berbagai pihak terutama para tokoh masyarakat, Dinas Pertanian Kabupaten Tasikmalaya mulai dari desa sampai kecamatan. Jika kondisi seperti ini terus dibiarkan, bukan suatu hal yang tidak mungkin beberapa tahun kedepan cerita tentang Manonjaya sebagai sentra salak lokal di wilayah priangan timur, mungkin hanya menjadi cerita dan catatan sejarah Kabupaten Tasikmalaya saja.

Untuk mengembalikan Manonjaya sebagai salah satu "sentra salak" di Kabupaten Tasikmalaya, harus menjadi perhatian serius pihak pemerintah Kabupaten Tasikmalaya dengan melibatkan seluruh lapisan masyarakat. Berkaitan dengan partisipasi masyarakat, keterlibatan masyarakat dalam berbagai program pemerintah merupakan hal yang penting dan ini menunjukkan sebuah demokrasi telah berjalan. Apabila meminjam istilah Jurgen Habermas dalam Kariangga yang disebut demokrasi radikal yang menekankan unsur partisipasi dan kesetaraan setiap anggota masya- rakat untuk berpatisipasi dalam proses pengambilan keputusan publik (Karianga, 2011), termasuk dalam hal ini keputusan untuk melestarikan tanaman salak Manonjaya yang sebagai ciri khas tanaman salak lokal Kabupaten Tasikmalaya.

Masih tentang partisipasi masyarakat, disebutkan bahwa dalam setiap pengambilan keputusan dan kebijakan diperlukan adanya partisipasi masyarakat agar pemenuhan hak-hak masyarakat tetap terpenuhi untuk pemecahan masalah dalam masyarakat untuk membangun daerahnya sendiri. Pelibatan publik atau masyarakat yang terwujud dalam perencanaan yang partisipatif dan membawa keuntungan yang subtantif, dimana keputusan publik yang diambil dapat membawa kepuasan masyarakat terhadap suatu proses pembangunan yang sedang berjalan.

Oleh karena demikian, berangkat dari permasalah tersebut di atas, peneliti bermaksud untuk mengkaji tentang komunikasi partisipatif masyarakat dalam upaya pelestarian tanaman salak lokal Manonjaya sebagai ciri khas tanaman holtikultura Kabupaten Tasikmalaya. Adapun mengenai pendekatan komunikasi partisipatif menurut UNESCO harus dijalankan melalui penyediaan akses media dan peningkatan partisipasi masyarakat dalam masyarakat dalam sistem komunikasi yang dijalankan. Sebagai sebuah komunikasi yang berbasis kepada masyarakat, praktek komunikasi partisipatif memiliki tujuan tidak hanya mengakomodasi kepentingan masyarakat dalam bidang informasi saja. Namun juga menjadikan media sebagai peningkatan kesadaran masyarakat terhadap lingkungan dimana mereka hidup, peningkatan kepercayaan diri dan kekuatan masyarakat lokal dalam menghadapi permasalahanpermasalahan mereka.

Berdasarkan permasalahan tersebut di atas, upaya pihak pemerintah Kabupaten Tasikmalaya untuk melestarikan tanaman salak Manonjaya sebagai salah satu produk unggulan pertanian Kabupaten Tasikmalaya, memerlukan dukungan dan partisipasi masyarakat. Dalam konteks komunikasi partisipatif berangkat dari asumsi bahwa masyarakat memiliki kemampuan untuk membangun dan menolong dirinya sendiri. Secara spesifik dapat dirumuskan sebagai berikut : Bagaimana keterlibatan mental dan perasaan masyarakat dalam upaya melestarikan tanaman salak lokal Manonjaya? Bagaimana kesediaan masyarakat untuk melakukan gerakan penanaman kembali salak di lingkungannya masing-masing? Bagaimana tanggung jawab masyarakat dalam memelihara dan mempertahankan tanaman salak sebagai salah 
satu produk unggulan Kabupaten Tasikmalaya? Bagaimana proses komunikasi partisipatif dalam membangun kesadaran masyarakat mengenai pentingnya melakukan pelestarian tanaman salak sebagai ciri khas tanaman unggulan Kabupaten Tasikmalaya?

Kemudian mengenai tujuan penelitian ini, ada beberapa tujuan yang diharapkan dari kegiatan penelitian ini yakni sebagai berikut :

1) Untuk mengetahui keterlibatan mental dan perasaan masyarakat dalam upaya melestarikan tanaman salak lokal Manonjaya.

2) Untuk mengetahui kesediaan masyarakat dalam melakukan gerakan penanaman kembali salak di lingkungannya masing-masing.

3) Untuk mengetahui tanggungjawab masyarakat dalam memelihara dan mempertahankan tanaman salak sebagai salah satu produk unggulan yang ada di Kabupaten Tasikmalaya.

4) Untuk mengetahui proses komunikasi partisipatif yang berlangsung dalam membangun kesadaran mengenai pentingnya melestarikan tanaman salak sebagai ciri khas tanaman unggulan Kabupaten Tasikmalaya.

\section{TINJAUAN PUSTAKA}

Tanaman salak memiliki nama ilmiah salacca edulis. Salak adalah merupakan tanaman asli Indonesia. Oleh karena itu, apabila kita bertanam salak maka berarti kita telah melestarikan dan meningkatkan produksi negeri sendiri. Tanaman salak termasuk golongan tanaman berumah dua (dio- ecus), artinya jenis tanaman yang membentuk bunga jantan pada tanaman terpisah dari bunga betinanya. Dengan kata lain, setiap tanaman memiliki satu jenis bunga atau disebut tanaman berkelamin satu (unisexualis) (Soetomo, 2001).
Nama salak (salacca edulis) disesuaikan dengan warna kulitnya yang coklat atau bahkan hitam. Berdasarkan ukurannya salak dibedakan menjadi dua yaitu besar dan kecil. Salak besar biasanya mempunyai kulit tebal dan bersisik kasar dengan daging buah tebal.Sedangkan salak kecil memiliki kulit tipis dengan sisik halus dan berdaging buah lebih tipis. Salak merupakan buah hortikultura asli Indonesia yang cukup produktif sehingga dapat dipanen sepanjang tahun. Buah ini terdiri dari tiga bagian, yaitu kulit buah, daging buah dan biji. Jenis salak yang sudah terkenal adalah salak lokal, salak bali dan salak pondoh. Diantara jenis salak yang sudah terkenal tersebut ternyata harga jual salak lokal per kilogramnya paling murah.Apalagi pada saat panen raya salak yang berlangsung dari bulan November- Januari, harga jual salak lokal semakin merosot karena kelebihan produksi dan kalah bersaing dengan salak unggul. Hal ini tentunya akan merugikan petani salak lokal. Berbicara lebih jauh tentang salak, di Indonesia terdapat beberapa jenis salak diantaranya :

\section{1) Salak pondoh}

Jenis buah salak ini kecil-kecil. Bentuknya tidak menarik akan tetapi memiliki daging buah yang rasanya manis dan enak dan sedikit sekali rasa sepetnya. Selain itu juga daging buahnya tipis sampai agak tebal dengan warna putih susu. Rasanya manis dan enak sejak buah masih muda sampai pada tingkat menjelang masak.

\section{2) Salak bali}

Jenis buah salak ini besarnya sedang, dalam waktu lima bulan saja buah sudah masak. Buah yang masak berwarna merah cokelat. Daging buah yang masak rasanya manis.

\section{3) Salak condet}


Salak ini berasal dari daerah cagar budaya Condet Jakarta Timur dan identik de ngan masyarakat betawi. Aroma salak ini paling harum dan tajam dibandingkan dengan salak jenis lainnya. Daging buahnya tebal. Masir, kesat, tak berarir dan berwarna putih kekuningan. Rasanya bervariasi dari kuran manis sampai dengan berasa manis.

\section{4) Salak padang sidempuan}

Salak padang sidempuan berasal dari da erah Tapanuli Selatan. Kulit buah salak ini berwarna hitam kecokelatan dan bersisik besar. Ciri khas utama salak ini adalah daging buahnya berwarna kuning tua berserabut merah. Rasa daging buahnya manis bercampur asam dan pada buah yang sudah tua rasa sepatnya hampir tidak ada.

\section{5) Salak gading}

Jenis buah salak ini kecil-kecil dengan warna kuning gading mengkilap. Daging buahnya berwarna putih kekuningan. Rasanya manis dan enak bila sudah masak. Daun salak gading lebih bersih dan agak kekuningan.

\section{6) Salak gula pasir}

Salak gula pasir merupakan salak satu kultivar dari salak Bali. Adapun yang menjadi kelebihan dari salak gula pasir ini adalah rasa daging buahnya yang sangat manis. Saking manisnya hingga mendekati kemanisan gula sehingga dinamakan salak gula pasir.

\section{7) Salak manonjaya}

Salak ini berasal dari salah satu wilayah yang ada di Kabupaten Tasikmalaya Jawa barat yakni Manonjaya. Jenis salak ini termasuk salak yang paling tebal daging buahnya jika dibandingkan dengan jenis salak lainnya, serta buahnya juga rata-rata besar, namun dari rasanya salak ini agak sedikit kesat (Nurhasanah, 2009)

Untuk menjelaskan tentang komunikasi partisipatif ini penulis mencoba mengkaitkan dengan komunikasi pembangunan. Dalam paradigma lama komunikasi pembangunan lebih menekankan pada proses komunikasi manusia dengan model komunikasi yang bersifat linier konvensional. Model ini merupakan gambaran proses komunikasi yang berlangsung secara linier dari sumber kepada penerima melalui media (sumber-pesan-media-penerima). Model linier-convensional tersebut dapat pula tergambarkan secara vertikal mengingat struktur stratifikasi sosial masyarakat terbagi menurut kelas atas, menengah dan bawah.

Adapun asumsi dasar paradigma ini adalah bahwa komunikasi sangat diperlukan dalam pemecahan masalah-masalah masyarakat, dengan memberikan penekanan elemen kognitif komunikasi. Dalam paradigma lama, komunikasi dirancang sedemikian rupa sehingga pesan-pesan persuasif yang telah dibakukan secara terpusat disuntikkan sebanyak mungkin kepada masyarakat. Semakin banyak pengaruh persuasif (yang positif dan konstruktif) disuntikkan, masyarakat semakin tergerak untuk melakukan apa yang diprogramkan dalam pembangunan, sesuai format pesan tersebut, karena pola pikirnya telah berhasil diubah lewat proses komunikasi itu.

Ada beberapa kelemahan paradigma lama ini, terletak pada diabaikannya aspek struktural dari proses pembangunan (kekuatan-kekuatan politik dan ekonomi, kaitan kultural, pengawasan 
media. Kemudian pada tahun 1976 Everett M. Rogers memproklamasikan usangnya paradigma lama komunikasi pembangunan, yang segera disusul tesis-tesis baru tentang perombakan komunikasi pembangunan. Dalam paradigma baru ini pembangunan tidak dipandang sebagai sesuatu yang lewat kegiatan dan ketrampilan yang diperoleh, melainkan sebagai sesuatu yang berlangsung sebagai suatu proses belajar. Oleh karena demikian munculah era paradigma baru komunikasi dalam pembangunan di Indonesia, yang lebih berciri partisipatif-horisontal.

Dalam paradigma komunikasi partisipatif horisontal ini, masyarakat diundang untuk berpartisipasi dalam proses komunikasi sampai dengan pengambilan keputusan. Dalam proses komunikasi, tidak hanya ada sumber atau penerima saja. Sumber juga penerima, penerima juga sumber dalam kedudukan yang sama dan dalam level yang sederajat. Karena itu kegiatan komunikasi bukan kegiatan memberi dan menerima melainkan "berbagi" atau "berdialog". Isi komunikasi bukan lagi "pesan" yang dirancang oleh sumber dari atas, melainkan fakta, kejadian, masalah, kebutuhan yang dikodifikasikan menjadi "tema". Dalam komunikasi partisipatif-horisontal, media dalam wujud hardware (perangkat keras, alat-alat, mekanik) maupun software (perangkat lunak, program-program) juga mengambil peranan penting. Tapi bukan sebagai sarana penyebar informasi atau pesan, melainkan sebagai sarana penyaji tema.

Praktek komunikasi partisipatif sebetulnya sudah dilakukan sejak lama di berbagai negara. Dalam konteks sejarah perkembangannya, komunikasi partisipatif merupakan solusi yang digunakan untuk memperbaiki kelemahan model komunikasi mekanistik yang dipraktekkan dalam pembangunan di berbagai negara dunia sejak tahun 1950-1970an. Pendekatan komunikasi mekanistik yang dipengaruhi oleh paradigma modernisasi menggunakan model komunikasi linear sebagai dasar berpikirnya. Model komunikasi linear ini menganggap bahwa komunikasi dijalankan dalam proses yang searah antara pengirim dan penerima pesan. Komunikasi partisipatif muncul sebagai salah satu solusi yang mampu memperbaiki ketimpangan model komunikasi linear. Komunikasi partisipatif ini memiliki sifat yang jauh berseberangan dengan pola komunikasi mekanistik.

Karakteristik yang khas dari komunikasi partisipatif ini terdapat pada penekanan partisipasi masyarakat ditingkat akar rumput. Masyarakat memiliki kemampuan untuk menyampaikan aspirasi dan kepentingannya. Bahkan, mereka dapat pula berpartisipasi pada proses pengambilan kebijakan hingga pelaksanaan pembangunan di lingkungan mereka. Berkaitan dengan hal ini bahwa pendekatan partisipatif berangkat dari asumsi masyarakat memiliki kemampuan untuk membangun dan menolong dirinya sendiri sehingga keterlibatan masyarakat merupakan elemen kunci dari pembangunan.

Kajian yang berkaitan dengan komunikasi partisipatif kemudian menempatkan dua pendekatan yang dapat dijadikan sebagai dasar berpikir.Yang pertama berasal dari pemikiran dialogical pedagogy yang dicetuskan oleh tokoh pendidikan Paulo Freire. Sedangkan yang kedua merupakan ide tentang konsep akses, partisipasi dan manajemen diri (self-management) yang dijabarkan pada pertemuan UNESCO tahun 1977. Jan Servaes dalam Richard, menjelaskan bahwa pendapat khas Freire dijalankan melalui dua strategi komunikasi. Pertama adalah dengan konsep dialogical communication yang memperlakukan setiap orang sebagai manusia utuh yang mampu menjadi subjek dalam setiap 
proses politik. Selain dipengaruhi oleh pemikiran eksistensialisme yang menghormati otonomi setiap orang sebagai manusia (Richards, 2001). Freire juga menempatkan sebuah teologi yang menuntut penghormatan kepada manusia lain (atheology that demands respect of otherness).

Sementara itu, strategi lain yang dijalankan dalam komunikasi partisipatif Freirian adalah dengan mengkaji pemikiran Karl Marx yang menyatakan bahwa manusia memiliki takdir yang melebihi hidup, yang hanya sekedar mengurusi permasalahan pemenuhan kebutuhan material saja, "that the human species has adestiny which is more than life as fulfillment of material need". Komunikasi partisipatif harus dijalankan melalui penyediaan akses media dan peningkatan partisipasi masyarakat dalam sistem komunikasi yang dijalankan. Pendekatan UNESCO dalam Jan Servaes lebih menempatkan titik fokusnya kepada permasalahan institusi media yang mampu membuat para partisipan mengelola komunikasi partisipatifnya secara mandiri (selfmanaged by those participating in it) (Servaes, 2002).

Praktek-praktek komunikasi partisipatif sebagai sebuah komunikasi yang berbasis kepada masyarakat, praktek komunikasi partisipatif memiliki tujuan tidak hanya mengakomodasi kepentingan masyarakat dalam bidang informasi saja. Ia menjadi salah satu media peningkatan kesadaran masyarakat terhadap lingkungan dimana mereka hidup, peningkatan kepercayaan diri dan kekuatan masyarakat lokal dalam menghadapi permasalahan permasalahan komunikasi memberi konsekuensi pada peranan baru komunikasi yang lebih ditekankanpada kebutuhan untuk membantu seluruh proses melalui pertukaran informasi secara interaktif atau transaksional. Dalam konsep komunikasi partisipatif, masyarakat sendiri yang semestinya mengidentifikasi kebutuhan akan informasi dan komunikasi. Masyarakat disini diposi- sikan sebagai mitra sejajar dalam mengembangkan pesan dan memproduksi media komunikasi. Melalui komunikasi partisipatif pula dapat mengurangi kemungkinan terjadinya konflik di antara kelompok, komunitas dan pemangku kepentingan lainnya.

Mengenai istilah komunikasi partisipatif, seringkali dikaitkan bahkan sering disamakan dengan istilah komunikasi pembangunan partipatif. Berkaitan dengan hal ini Dragon dalam Servaes, mengungkapkan perbedaan komunikasi pembangunan partisipatif dengan strategi komunikasi. Adapun mengenai perbedaan ini dari kedua bentuk komunikasi ini antara lain (Servaes, Communication for Development Approaches of Some Governmental and Non-Governmental Agencies, 2002):

a) Dalam komunikasi partisipatif masyarakat adalah aktor yang dinamis, aktif terlibat dalam proses perubahan sosial dan turut mengendalikan cara-cara komunikasi dan isi komu- nikasi, alih-alih sebagai penerima informasi dan petunjuk-petunjuk berperilaku yang pasif, sementara orang lain yang membuat keputusan kehidupan mereka.

b) Dalam komunikasi partisipatif, proses komunikasi disesuaikan dengan komunitas atau kelompok sosial tertentu, baik menyangkut isi, bahasa, budaya maupun media yang digunakan.

c) Dalam komunikasi partisipatif, dialog yang dilakukan berbasis komunitas dan cara-cara komunikasi ditujukan untuk membantu mengidentifikasi, mendefinisikan perbedaan antara felt needs dan real needs.

d) Dalam komunikasi partisipatif, proses komunikasi merupakan "hak rakyat" yang 
dimiliki untuk memberikan kesempatan yang sama pada komunitas.

e) Dalam komunikasi partisipatif, proses untuk mencapai penyadaran dan pemahaman yang mendalam tentang realitas sosial, masalah serta solusinya.

Dalam menerapkan komunikasi partisipatif memungkinkan; (1) terjadinya komunikasi personal yang dialogis antara masyarakat dan agen pembangunan desa, (2) pemanfaatan media tradisional atau media rakyat yang lebih intensif, (3) tumbuhnya aktifitas sosial secara berkelompok, (4) dan berkembangnya media komunitas.

\section{METODE PENELITIAN}

Dalam penelitian ini, metode campuran (mixed method) dianggap pantas untuk membantu memecahkan masalah ini. Mengenai pengertian penelitian campuran atau mixed method Denscombe sebagaimana yang dikutif Nusa Putra dan Hendarman dalam bukunya Metode Riset Campur Sari, mengatakan bahwa metode gabungan adalah suatu pendekatan kombinasi sebagai alternative terhadap pengunaan metode tunggal dalam suatu penelitian (Nusa \& Hendarman, 2013). Hakekatnya metode gabungan (mixed method) adalah merupakan strategi yang mengunakan penelitian kuantitatif dan kualitatif dalam satu penelitian. Berkaitan dengan metode gabungan atau metode campuran ini, akan memberikan hasil yang lebih baik karena memiliki kekayaan data, karena dapat memadukan atau mengkombinasikan data kuantitatif dan kualitatif. Dengan demikian tetap terjadi pembedaan antara data kuantitatif dan kualitatif, namun kini keduanya tidak dipisahkan, tetapi justru dipadukan untuk saling memperkuat, menjelaskan dan memperdalam hasil penelitian.

Masih tentang penelitian campuran, salah satu pendapat lain yang lebih lengkap yang menjelaskan tentang metode gabungan (mixed method) ini dikemukakan oleh John W Creswell yang mengatakan :

"Penelitian metode campuran merupakan pendekatan penelitian yang mengkombinasikan atau mengasosiasikan bentuk kualitatif dan bentuk kuantitatif. Pendekatan ini melibatkan asumsi-asumsi filosofis, pendekatan kuantitatif dan kualitatif, dan pencampuran (mixing) kedua pendekatan tersebut dalam satu penelitian. Pende- katan ini lebih kompleks dari sekedar mengumpulkan dan menganalisis dua jenis data, ia juga melibatkan fungsi dari pendekatan penelitian tersebut secara kolekstif sehingga kekuatan penelitian ini secara keseluruhan lebih besar ketimbang penelitian kuantitatif dan kualitatif" (Creswell, 2010).

Nusa Putra dan Herndarman merangkum sejumlah pendapat tentang penelitian campuran (mixed method) yang mengatakan, bahwa penelitian campuran atau mixed method adalah merupakan perpaduan atau kombinasi penelitian kuantitatif dan kualitatif mulai dari tataran atau tahapan pengumpulan dan analisis data, penggunaan teknik-teknik penelitian, rancangan penelitian, sampai pada tataran pendekatan dalam satu penelitian tunggal (Nusa \& Hendarman, 2013). Jadi dengan demikian suatu penelitian dikatakan penelitian campuran jika mengintegrasikan data, teknik, rancangan juga pendekatan kuantitatif dan data kualitatif dalam satu penelitian 
Kemudian design yang digunakan dalam metode campuran (mixed method) ini penelitian menggunakan parallel mixed method. Dalam design parallel mixed method dimulai dari pernyataan penelitian (research question). Adapun pertanyaan dalam penelitian ini adalah "Bagaimana partisipasi masyarakat dalam melestarikan tanaman salak lokal Manonjaya“. Selanjutnya untuk design campuran digunakan teknik pengumpulan data melalui survey yakni menggunakan kuantitatif, participantobservation (qualitative) serta indepth interview (qualitative). Data yang terkumpul dari ketiga teknik ini selanjutnya dianalisis dan dinterpretasikan. Untuk selanjutnya temuantemuan yang diperoleh dari ketiga teknik penelitian bertujuan untuk saling melengkapi.

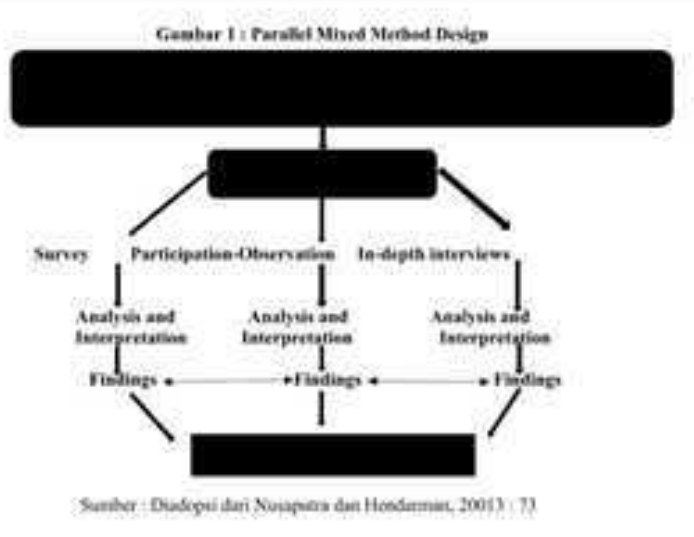

Gambar 1 : Parallel Mixed Method Design

Sumber: (Nusa \& Hendarman, 2013)

\section{HASIL DAN PEMBAHASAN}

Adanya keengganan dari sebagian petani salak lokal yang ada di wilayah Manonjaya untuk tidak meneruskan kegiatannya sebagai petani salak, bukanlah suatu masalah yang sederhana. Banyak faktor yang menyebabkan mereka memutus hal ini, mulai dari harga salak yang murah, pengetahuan tentang pemasaran rendah, maupun kemampuan dalam mengolah salak menjadi produk makanan lainnya. Oleh karena demikian untuk mengajak masyarakat Manonjaya berpartisipasi nenanam kembali salak sebagai ciri khas daerahnya bukanlah suatu hal yang mudah. Oleh karena itu perlu adanya solusi yang komprehensif dan efektif bagi pemecahan masalah tersebut.

Solusi yang dimaksud di atas hanya bisa dirumuskan jika masalah tentang mengapa para petani salak di wilayah Manonjaya enggan untuk melanjutkan sebagai petani salak, bisa dipahami secara mendalam dan ketahui akar permasalahannya. Survey yang telah dilakukan Biro Pusat Statistik Kabupaten Tasikmalaya dapat menjadi pintu masuk untuk mendalami hal tersebut. Mengenai keterlibatan mental dan perasaan masyarakat petani Salak di Kecamatan Manonjaya dan kecamatan Cineam, terlihat dari adanya rasa kekhawatiran di kalangan masyarakat khususnya para petani salak dengan semakin berkurangnya produksi salak di daerah mereka.

Padahal selama ini tanaman salak telah menjadi komoditas unggulan dan menjadi tanaman yang menjadi ciri khas daerah mereka. Untuk menjawab kehawatiran ini beberapa tokoh masyarakat yang ada di Desa Pasirbatang Kecamatan Manonjaya, tokoh masyarakat Desa Pasirmukti, Desa Cikondang Kecamatan Cineam serta serta beberapa para petani salak mulai membicarakan tentang upaya melestarikan tanaman salak Manonjaya. Selain itu juga pertemuan ini mendapat dukungan dari pihak pemerintah. Hal ini terlihat adanya keterlibatan dari pihak pemerintah baik pemerintah Desa, 
pihak Kecamatan serta Kabupaten Tasikmaya dan pihak terkait lainnya untuk memberikan dukungan dan bimbingan teknis, sehingga para untuk ke depannya antara petani salak tidak selalu terpuruk dan bisa menikmati jerih payahnya sebagai petani.

Kemudian mengenai kesediaan masyarakat khususnya dari para petani salak untuk menanam kembali tanaman salak di tanah miliknya. Berdasarkan hasil observasi terungkap bahwa beberapa daerah yang selama ini menjadi sentra penghasil salak seperti Desa Pasirbatang dan Desa Pasirmukti dan Desa Cikondang para petani salak mulai menanam kembali tanahnya dengan bibit salak. Selain itu juga adanya keterlibatan Dinas Pertanian dan pihak pemerintah Kecamatan dan Kabupaten dalam mendorong para petani salak untuk kembali menanam salak terlihat dari beberapa program penyuluhan dan pertemuan yang rutin dilakukan serta membantu dalam penyediaan benih tanaman salak dan melakukan pendampingan pada petani salak.

Sebagai wujud tanggungjawab dari masyarakat untuk mempertahankan tanaman salak, beberapa petani salak berupaya untuk mempertahankan tanaman salak mereka yang belum punah dengan tetap menjaga dan memelihara tanaman salak mereka. Sedangkan upaya lain yang mereka lakukan juga adalah dengan mencari bibit tanaman salak dengan mencoba memadukan antara tanaman salak lokal dengan salak pondoh. Dalam beberapa pertemuan dengan kelompok petani salak dan dinas tenian dan pertamanan Kabupaten Tasikmalaya juga dising- gung banyak cara persilangan antara tanaman salak lokal dan salak pondoh. Melalui cara ini para petani bermaksud ingin meningkatkan kualitas rasa salak lokal yang awalnya agak kesat menjadi manis seperti salak pondoh namun tetap mempertahankan ciri khas salak lokalnya yang besar dan warna coklat kehitam-hitaman.

Dalam komunikasi partisipasi masyarakat berasumsi bahwa pesan komunikasi tidak bersifat linier dari atas ke bawah seperti pada konsep pembangunan sebelumnya. Namun dalam komunikasi partisipasi masyarakat terlibat secara aktif dalam membicarakan dan menentukan ide untuk pemecahan masalah. Adapun dalam konteks komunikasi partisipasi masyarakat dalam upaya pelestarian tanaman salak lokal di Kecamatan Manonjaya Kabupaten Tasikmalaya, terlihat dengan adanya keterlibatan masyarakat yakni para petani salak, para tokoh masyarakat, untuk bersama-sama memecahkan masalah tentang semakin langkanya tanaman salak di wilayah Kecamatan Manonjaya dan Kecamatan Cineam. Hal ini juga telihat dengan keterlibatan masyarakat khususnya para tokoh masyarakat dan para petani salak, yang berperan tidak hanya sebagai pendengar akan tetapi juga mereka sebagai aktor yang turut membicarakan, memikirkan dan menentukan upaya pelestarian tanaman salak lokal Manonjaya sebagai salah satu tanaman komiditas unggulan Kabupaten Tasikmalaya.

\section{SIMPULAN}

Berdasarkan analisa dari sumber data dan pembahasan penelitian diatas, maka rangkuman atau ringkasan adalah sebagai berikut: 
1. Banyak faktor yang menyebabkan petani salak di Manonjaya berhenti atas kegiatannya sebagai petani salak. Mulai dari harga salak yang murah, pengetahuan tentang pemasaran rendah, maupun kemampuan dalam mengolah salak menjadi produk makanan lainnya. Adanya rasa kekhawatiran di kalangan masyarakat khususnya para petani salak dengan semakin berkurangnya produksi salak di daerah mereka.

2. Terungkap bahwa beberapa daerah yang selama ini menjadi sentra penghasil salak seperti Desa Pasirbatang dan Desa Pasirmukti dan Desa Cikondang para petani salak mulai menanam kembali tanahnya dengan bibit salak setelah melalui berbagai dukungan dan bimbingan teknis yang melibatkan pihak pemerintah, baik pemerintah Desa, pihak Kecamatan serta Kabupaten Tasikmaya dan pihak terkait lainnya.

3. Upaya pelestarian tanaman salak lokal di Kecamatan Manonjaya Kabupaten Tasikmalaya, terlihat juga selain dengan dukungan pemerintah, yaitu dengan adanya keterlibatan masyarakat yakni para petani salak itu sendiri, para tokoh masyarakat, untuk bersama-sama memecahkan masalah tentang semakin langkanya tanaman salak di wilayah Kecamatan Manonjaya dan Kecamatan Cineam. Pihak-pihak yang terlibat tersebut turut membicarakan, memikirkan dan menentukan upaya pelestarian tanaman salak lokal Manonjaya sebagai salah satu tanaman komiditas unggulan Kabupaten Tasikmalaya.

\section{DAFTAR PUSTAKA}

Creswell, J. W. (2010). Research Design: Pendekatan Kualitatif, Kuantitatif, dan Mixed. Yogyakarta: Pustaka Pelajar.

Karianga, H. (2011). Partisipasi Masyarakat dalam Pengelolaan Keuangan Daerah (Persepektif Hukum dan Demokrasi. Bandung: Alumni.

Nurhasanah, L. (2009). Analisis Finansial Pengolahan Salak Dan Prosepek Pengembangan di Kabupaten Tapanuli Selatan. Medan: USU.

Nusa, P., \& Hendarman. (2013). Metode Riset Campur Sari : konsep, strategi dan aplikasi. Jakarta : Indeks.

Richards, M. (2001). Participatory Communication research for Democracy and Social Change. Paris: UNESCO.

Servaes, J. (2002). Approaches to Development Communication. Paris: UNESCO.

Servaes, J. (2002). Communication for Development Approaches of Some Governmental and Non-Governmental Agencies. Paris: Unesco.

Soetomo. (2001). Teknik Bertanam Salak. Bandung : Sinar Baru Algesindo. 
